\title{
Learning Design to Integrate Scientific Character Values with Green Chemistry Insight in Basic Chemistry Course
}

\author{
Mitarlis, U. Azizah \& B. Yonata \\ Universitas Negeri Surabaya, Surabaya, Indonesia \\ mitarlisunesa@ac.id
}

\begin{abstract}
It has been done a curriculum analysis in the form of research development to find out learning materials on Basic Chemistry course with green chemistry insight in order to realize green education. This is research and development study. This article presents the results of research at the preliminary study stage supported by references study. The results of mapping on learning materials in the Basic Chemistry courses that can lead the scientific character values with green chemistry insight, are; first, in an introduction; scientific method, the nature of matter, elements, compounds, and mixtures. Second, learning activities formulation integrates green chemistry principles in each learning material. Students learning experience can be discussion, question and answer, practice questions, create concept maps, laboratory activity, and create project tasks. Model, strategy, or method of learning that can integrate scientific character values on basic chemistry course such as discussion, cooperative, and project-based learning.
\end{abstract}

Keywords-learning; green chemistry; environmental; curriculum

\section{INTRODUCTION}

Environmental issues have become one of the most important and most noticed issues in recent years. The word "green" has become a new trend in human daily life. Every element of society begins to realize that the Earth is not in good condition, and must take action to save our Earth together. Green chemistry is a philosophy or concept that encourages the design of a product or process which reduces or eliminates the use and form of harmful substances [5]. The principles of green chemistry can be adapted for application in human attitudes and actions in an effort to save the environment that can be realized through green education. This research has begun with chemical research on Green Chemistry, and students' understanding of character values [6].

Environmental aspects also become one of the basic references in every development process. College is a place where people are educated and matured in order to provide solutions in nation's problems. The level of progress of a country can be seen from the quality of college. Therefore, it should be a university to spearhead the forefront in solving a nation's problems, including environmental problems.
The learning that related to environmental issues actually can be integrated in each course. Green chemistry is also called sustainable chemistry, a chemical philosophy that encourages the design of products and processes to reduce or eliminate the use and creation of hazardous chemicals [5]. The Green Education Foundation (GEF) with the motto'creates future sustainability through education', has ongoing programs [8]. In formal education, continuing education can be embedded in compulsory courses. From the investigation with systematic review method of several related research articles on how sustainable education approaches have been developed, the taxonomy is derived that: 1) the integration of continuing education can be broadly crossed with curricula, courses, or institutions. 2) through compulsory subjects, 3) the study material component of a compulsory subject, and 4) the chosen subjects [2].

Green chemistry has 12 elements that can be adapted for application in human attitudes and actions in order to save the environment [12]. Caring on environmental action can be done early by implementing in the field of education at all levels that can be realized through green education. Mitarlis (2015) conducted a research on analysis of scientific character values with green chemistry insight in order to realize green education through Basic Chemistry course got some character value that can be implemented in learning. They are: 1) common character values that can be raised in Basic Chemistry lectures include: honest, disciplined, thorough, meticulous, careful, hard work, responsibility, analytical thinking, critical thinking, creative, and caring environment. 2) The identification of the principle of green chemistry as the basis of character value with green chemistry in order to realize green education found 7 principles, such as: waste prevention, use renewable feedstock, atom economy, energy efficiency, design for degradation, real-time analysis for pollution prevention and inherently chemistry safer for accident prevention. 3) Obtained value of green chemistry science of the mapping results include: honesty, meticulous curiosity, care about the environment (smart water, smart energy, smart mobility, smart rubbish), efficient and creative (utilization of natural materials for the benefit of human and learning Chemistry), and others [6]. The findings 
are will give great benefit if they can be implemented in subsequent learning.

This article discusses the results of research on curriculum analysis in research development of Basic Chemistry learning with green chemistry insight in order to realize green education. Basic Chemistry curriculum is formulated in the Semester Lesson Plan that is applied in Chemistry Department at Surabaya State University. Research and development is done to describe learning materials feasibility of Basic Chemistry course which was developed by green chemistry insight. This article is aimed to: 1) map the study materials in the Basic Chemistry 1 course which can lead to the scientific character with green chemistry insight; 2) formulate learning activities that can integrate green chemistry principles in every study material. 3) determine the model or strategy, learning method that can cover the green chemistry insight in basic chemistry course.

\section{METHOD}

The type of this research is a development research, which uses ( $\mathrm{R} \& \mathrm{D}$ ) development methods proposed by Dick and Carey [9].

Overall, there are 6 stages the development stages. They are: preliminary study, reference study, material development, expert evaluation, empirical evaluation and final product. In principle, this method consists of three stages, namely: preliminary study stage supported by reference studies, development phase, and evaluation phase by expert evaluation.

This article presents the results of the research obtained only two stages; the preliminary study and reference study. The preliminary study stage was analyzed by curriculum of Basic Chemistry I course to determine the learning activities that can be integrated into science character values and green chemistry insight. The analysis is linked to a literature study of green chemistry principles in the previous research and future research perspectives. Also, it is conducted a need analysis (need assessment) underlying the main research which develop basic chemistry learning materials with green chemistry insight.

\section{RESULTS AND DISCUSSION}

The curriculum analysis is conducted on Semester Guideline Course (SGC) or syllabus in Basic Chemistry I course. Based on the learning outcome, students' final capability depends on learning achievement indicator, study material and learning strategy. In this curriculum analysis, mapping and linkage between the syllabus components are used. Student learning experience is associated with the emergence of sci- ence character values with green chemistry and the form of learning activities that will be experienced by students.

The summary of the Semester Guideline Course $(S G C)$ as an example of mapping results up to several study materials is presented in Table 1. While a summary of mapping results related to the green chemistry student learning experience is presented in Table II.

TABLE I. EXAMPLE OF SEMESTER Guideline Course( $S G C)$ of BASIC CHEMISTRY SUBJECT

\begin{tabular}{|c|c|c|c|c|}
\hline No. & Competencies & Indicator & Matter & $\begin{array}{c}\text { Learning } \\
\text { Experience }\end{array}$ \\
\hline 1 & \begin{tabular}{l}
\multicolumn{1}{c}{ Compre- } \\
hending \\
Chemistry as \\
result of scien- \\
tific activities \\
that discuss \\
about matter \\
and universal \\
properties.
\end{tabular} & $\begin{array}{l}\text { 1. Explain the } \\
\text { step of sci- } \\
\text { entific } \\
\text { methods. } \\
\text { 2. Explain the } \\
\text { intensive } \\
\text { and exten- } \\
\text { sive prop- } \\
\text { erties. } \\
\text { 3. Define the } \\
\text { physical } \\
\text { and chemi- } \\
\text { cal proper- } \\
\text { ties of ele- } \\
\text { ment, } \\
\text { compound } \\
\text { and mix- } \\
\text { ture }\end{array}$ & $\begin{array}{l}\text { Introduction: } \\
\text { steps of scien- } \\
\text { tific method, } \\
\text { Chemistry as } \\
\text { scientific } \\
\text { activity, mat- } \\
\text { ter and ener- } \\
\text { gy, intensive } \\
\text { and extensive } \\
\text { properties, el- } \\
\text { ement, com- } \\
\text { pound and } \\
\text { mixture. }\end{array}$ & $\begin{array}{l}\text { 1.1 Question } \\
\text { and answer } \\
\text { about the } \\
\text { steps of sci- } \\
\text { entific } \\
\text { method } \\
\text { 1.2 Giving ex- } \\
\text { amples of } \\
\text { intensive } \\
\text { and exten- } \\
\text { sive proper- } \\
\text { ties. } \\
1.3 \quad \text { Making } \\
\text { concept map } \\
1.4 \text { Define } \\
\text { each concept } \\
1.5 \text { Practice } \\
\text { about ele- } \\
\text { ment, com- } \\
\text { pound, and } \\
\text { mixture }\end{array}$ \\
\hline 2 & $\begin{array}{l}\text { Compre- } \\
\text { hending the } \\
\text { basic of stoi- } \\
\text { chiometri } \\
\text { mainly: basic } \\
\text { law of chemis- } \\
\text { try, atom and } \\
\text { molecule, } \\
\text { mole concept, } \\
\text { and Avogadro } \\
\text { constanta, } \\
\text { compound } \\
\text { formula, } \\
\text { chemical reac- } \\
\text { tion, as well as } \\
\text { molarity and } \\
\text { equivalency }\end{array}$ & $\begin{array}{l}\text { 1. Explain } \\
\text { the Basic } \\
\text { Low of } \\
\text { Chemistry } \\
\text { 2. Define at- } \\
\text { om, mole- } \\
\text { cule, and } \\
\text { mole con- } \\
\text { cept } \\
\text { 3. Apply } \\
\text { Avogadro } \\
\text { constanta } \\
\text { and com- } \\
\text { pound } \\
\text { formula. } \\
\text { 4. Apply } \\
\text { chemical } \\
\text { reaction } \\
\text { and bal- } \\
\text { ancing, } \\
\text { molarity, } \\
\text { and equivalen- } \\
\text { cy in } \\
\text { problem } \\
\text { exercise }\end{array}$ & $\begin{array}{l}\text { Stoichiome- } \\
\text { try: Chemis- } \\
\text { try Basic } \\
\text { Law, Atom, } \\
\text { and molecule, } \\
\text { mole concept } \\
\text { Avogadro } \\
\text { constanta, } \\
\text { compound } \\
\text { formula, } \\
\text { chemical re- } \\
\text { action, as } \\
\text { well as molar- } \\
\text { ity and equiv- } \\
\text { alency }\end{array}$ & $\begin{array}{l}\text { 1.1 Problem } \\
\text { solving ex- } \\
\text { ercise of } \\
\text { Chemistry } \\
\text { Basic Law. } \\
\text { 1.2 Making } \\
\text { concept map } \\
\text { of atom and } \\
\text { molecule, as } \\
\text { well as mole } \\
\text { concept. } \\
\text { 1.3 Problem } \\
\text { solving ex- } \\
\text { ercise of } \\
\text { chemical re- } \\
\text { action and } \\
\text { balancing, } \\
\text { molarity, } \\
\text { and equiva- } \\
\text { lency, } \\
\text { 1.4 Practice of } \\
\text { Chemistry } \\
\text { Basic Law } \\
\text { and chmical } \\
\text { reactions } \\
\text { with green } \\
\text { chemistry } \\
\text { insight. }\end{array}$ \\
\hline 3 & $\begin{array}{l}\text { Compre- } \\
\text { hending atom- } \\
\text { ic structure } \\
\text { development }\end{array}$ & $\begin{array}{l}\text { 1. Explain } \\
\text { funda- } \\
\text { mental } \\
\text { particle of }\end{array}$ & \begin{tabular}{l}
\multicolumn{1}{c}{ Atomic } \\
Structure: \\
Basic parti- \\
cle, hydrogen
\end{tabular} & $\begin{array}{l}1.1 \text { Study of } \\
\text { basic parti- } \\
\text { cle of atom. } \\
1.2 \text { Making }\end{array}$ \\
\hline
\end{tabular}




\begin{tabular}{|c|c|c|c|c|}
\hline No. & Competencies & Indicator & Matter & $\begin{array}{c}\text { Learning } \\
\text { Experience }\end{array}$ \\
\hline & $\begin{array}{l}\text { and discovery } \\
\text { of basic parti- } \\
\text { cle of atom, } \\
\text { according to } \\
\text { Rutherford, } \\
\text { Bohr, quantum } \\
\text { mechanic and } \\
\text { electron con- } \\
\text { figuration. }\end{array}$ & $\begin{array}{l}\text { atom. } \\
\text { 2. Explain } \\
\text { atomic } \\
\text { theory de- } \\
\text { velopment } \\
\text { 3. Determine } \\
\text { electron } \\
\text { configura- } \\
\text { tion many } \\
\text { atoms. }\end{array}$ & $\begin{array}{l}\text { atom spec- } \\
\text { trum, and } \\
\text { atomic model } \\
\text { of Rutherford, } \\
\text { Bohr, and } \\
\text { quantum me- } \\
\text { chanical, } \\
\text { electron con- } \\
\text { figuration. }\end{array}$ & $\begin{array}{l}\text { media of } \\
\text { atomic mod- } \\
\text { el imitation } \\
1.3 \text { Making } \\
\text { concept map } \\
\text { of atomic } \\
\text { theory de- } \\
\text { velopment. } \\
1.4 \text { Problem } \\
\text { solving ex- } \\
\text { ercise of } \\
\text { electron } \\
\text { configura- } \\
\text { tion }\end{array}$ \\
\hline
\end{tabular}

Based on Table 1, show the results of the mapping of learning materials in the basic chemistry I course, which can lead to the scientific character with green chemistry. A formulation of learning activities that can integrate green chemistry principles in every learning material both at the time of classroom learning with non-practicum worksheet media and learning in laboratories with practice worksheet. Strategy, model, or method of learning can cover basic chemistry lesson with green chemistry in learning model. Discussion of learning models are used at the beginning of the meeting with preliminary study materials which largely covers scientific methods, material properties, and studies of elements, compounds and mixtures. Learning experience was done by doing experiments in the laboratory to learn the elements, compounds and mixtures. The example result of mapping of learning materials was presented in Table II.

TABLE II. THE RELATIONSHIP OF TOPIC, LEARNING EXPERIENCE, GREEN CHEMISTRY INSIGHT, AND LEARNING MATERIALS

\begin{tabular}{|c|c|c|c|c|}
\hline No. & Matter & $\begin{array}{l}\text { Learning Expe- } \\
\text { rience }\end{array}$ & $\begin{array}{l}\text { Model/ } \\
\text { strategy/ } \\
\text { method }\end{array}$ & $\begin{array}{l}\text { Green chemistry } \\
\text { insight }\end{array}$ \\
\hline 1 & $\begin{array}{l}\text { Introduc- } \\
\text { tion: steps } \\
\text { of scientific } \\
\text { method, } \\
\text { Chemistry } \\
\text { as scientific } \\
\text { activity, } \\
\text { matter and } \\
\text { energy, in- } \\
\text { tensive and } \\
\text { extensive } \\
\text { properties, } \\
\text { elemen, } \\
\text { compound } \\
\text { and mix- } \\
\text { ture. }\end{array}$ & $\begin{array}{l}\text { 1. Question } \\
\text { and answer } \\
\text { about the } \\
\text { steps of sci- } \\
\text { entific } \\
\text { method } \\
\text { 2. Giving ex- } \\
\text { amples of } \\
\text { intensive } \\
\text { and exten- } \\
\text { sive proper- } \\
\text { ties. } \\
\text { 3. Making } \\
\text { concept map } \\
\text { 4. Define each } \\
\text { concept }\end{array}$ & $\begin{array}{l}\text { Model: } \\
\text { Class } \\
\text { Discus- } \\
\text { sion } \\
\text { learning } \\
\text { model } \\
\text { (Think } \\
\text { Pair } \\
\text { Share } \\
\text { type) } \\
\\
\text { Learning } \\
\text { Strategy: } \\
\text { making } \\
\text { concept } \\
\text { map }\end{array}$ & $\begin{array}{l}\text { Principle No. 1: } \\
\text { Waste preven- } \\
\text { tion } \\
\text { Principle No. 6: } \\
\text { Energy Efficien- } \\
\text { cy, } \\
\text { (include materi- } \\
\text { al, water and } \\
\text { substance effi- } \\
\text { ciency } \\
\text { Principle No. } 5 \\
\text { Benign solvent } \\
\text { using } \\
\text { Principle no. } 12 . \\
\text { Inherently acci- } \\
\text { dent prevention }\end{array}$ \\
\hline
\end{tabular}

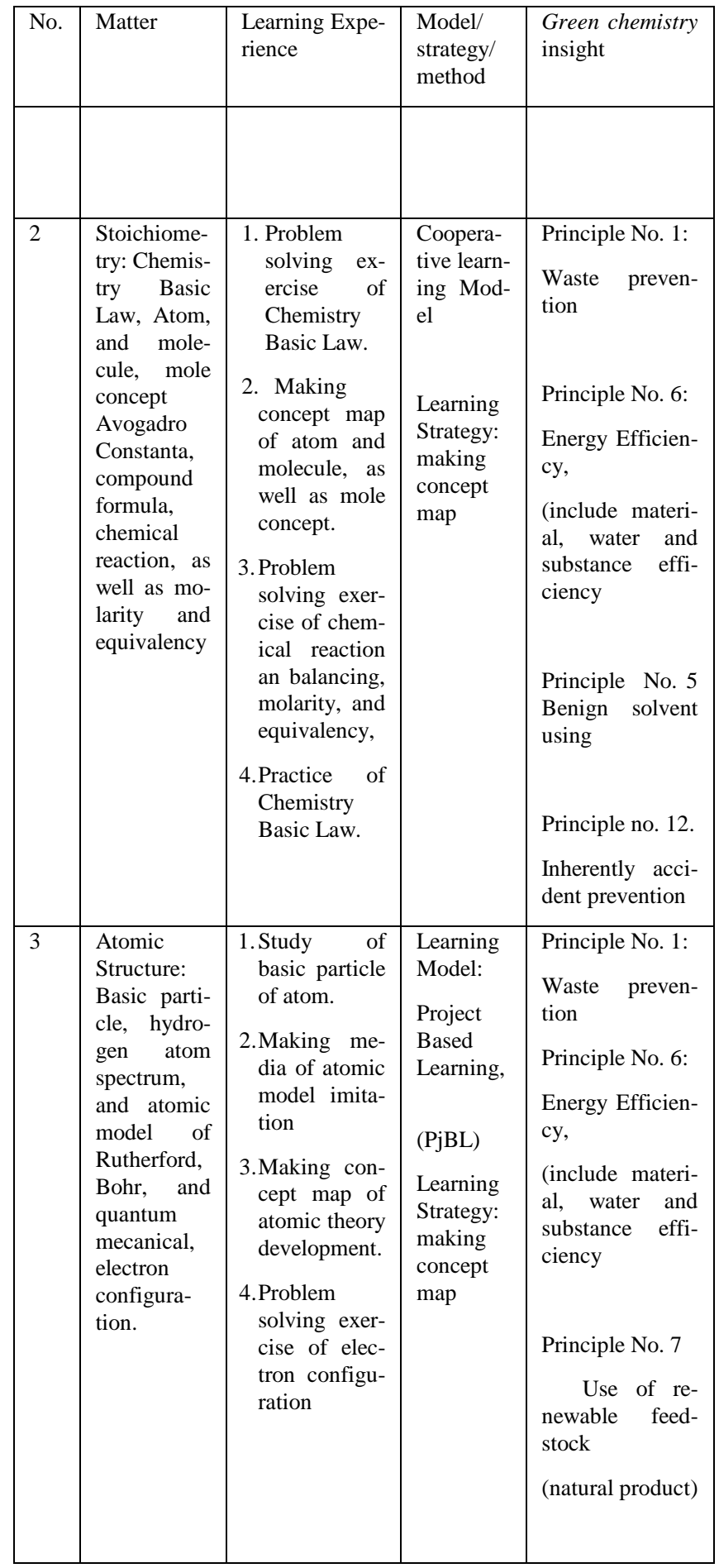

Based on data on Table II, the learning experiences were designed by integrating green chemistry principles. They are; principle no1: Prevent/ reduce the formation of waste; Principle no. 6: Save energy, save chemicals when practicum; Principle No. 5: using solvents or safe chemicals; and Principle no. 12. Inherently prevent accidents. Its principles are important to be adapted as a basis of scientific character values. Aighewi \& Osaigbovo (2010) assumed that students' opinion related to 
global environmental literacy is used as requirement to comprehend the environmental literacy to non-science students [1].

Stevens (2014), and also Li \& Lang (2015) found the affect of formal education and family toward orientation of human and natural environment relationship to students in China $[10,4]$. Also, orientation of students and pre service teacher to the environment after they took green chemistry lecture, showed the increasing of ecocentrism attitude and decreasing of homocentrism and egocentrism as well [3].

\section{CONCLUSION}

Based on the results of development research on the first stage with preliminary studies by mapping the Basic Chemistry I curriculum and the study of literature related to learning, the principle of green chemistry can be concluded that:

The results of mapping of study materials in the Basic Chemistry I course can bring the scientific character with green chemistry insight. They are: on the initial of study materials which is stated in the introduction of the scientific method, the nature of matter, elements, compounds, and mixtures. Learning activities can be integrated to green chemistry principles in every learning material, both at the time of learning in the classroom with non-practicum worksheet media and learning in laboratories with practicum worksheet as well. Students' learning experience can be in the form of discussion, question and answer, practice questions, create concept maps, practicum, and create project tasks. Strategic models or learning methods which cover basic chemistry lessons with green chemistry; such as discussion, cooperative, and project-based learning model.

\section{REFERENCES}

[1] I. T. Aighewi, and U. A. Osaigbovo, Students' perspectives on worldwide "greening" of tertiary education curricula. Research in Science Education, 40: 625-637, 2010.
[2] N. S. Evans, Approaches to embedding sustainability in teacher education: A synthesis of the literature. Teacher and Teaching Education. 63: 405- 417, 2017.

[3] M. Karpudewan, Z. Ismail, and M. W. Roth, "The efficacy of green chemistry laboratory based pedagogy: changes in environmental values of Malaysia pre-service teachers," International Journal of Science and Mathematics Education, vol. 10, pp. 497-529, 2011

[4] W. Li and G. Lang, Effects of green school and parents on children's perceptions of human-nature relationships in China. Child Indicators Research, vol. 8, no. 3, pp. 587-604, 2015.

[5] S.E. Manahan, Green chemistry and the ten commandments of sustainability. Columbia, Missouri USA: ChemChar Research, 2006.

[6] Mitarlis, Pengembangan metode sintesis furfural berbahan dasar campuran limbah pertanian dalam rangka mewujudkan prinsip Green Chemistry. Jurnal Manusia dan Lingkungan, 18(3). PSLH UGM Yogyakarta. Center of Environmental Studies Gajah Mada University, 2011.

[7] Mitarlis, Y. Bertha, H. Rusly, Analisis nilai karakter sains berwawasan Green Chemistry pada perkuliahan Kimia Dasar dalam rangka mewujudkan Green Education, Proceeding SNKPK vol.1., 2015, ISBN: 978-602-14397-1-5 Seminar Nasional Kimia dan Pendidikan Kimia 2015. Jurusan Kimia FMIPA Universitas Negeri Semarang, 2015.

[8] GEFS, ustainability Programs! Green Education Foundation (GEF) $\mathrm{http} / / /$ www.green educationfoundation.org/teacher-resources.html, 2016.

[9] A. Sjaifullah, "Developing speaking materials for the students of Mechanical Engineering at State Polytechnic of Malang," Jurnal Linguistik Terapan. (online). http://jlt-polinema.org/ accessed 7 November 2015, 2011.

[10] D. Stevens, Creating greener citizens: Political liberalism and a robust environmental education. Studies in Philosophy and Education, 33(5): 545-562, 2014.

[11] UNESCO, Environmental Education: Curicullum and Learning, Paris : IEEP, ISBN: 92-803-1288-X, 2006.

[12] P . T Anastas, J . C . Warner, Green Chemistry: Theory and Practice . New York: Oxford University Press, pp. 30, 1998.

[13] H. Timperley, Teacher professional learning and development. Internasional Academy of Education and International Bureau Of Education, 2008

[14] W. Louw, Green Curriculum : Sustainable Learning at a Higher Education Institution, The Internasional Review of Research in Open and Distance Learning, vol. 14 no. 1, 2013.

[15] S. Santone, S. Saunders, and C. Seguin, "Essential Elements of Sustainability in Teacher Education," Journal of Sustainability Education, vol. 6, ISSN: 2151-7452, May 2014. 